\title{
Difference of nitrogen contents determined by the combustion and Kjeldahl method in response to nitrate nitrogen in some feedstuffs ${ }^{*}$
}

\author{
W.S. Guo, L.P. Ren, Z.M. Zhou and Q.X. Meng' \\ State Key Laboratory of Animal Nutrition, College of Animal Science \& Technology, \\ China Agricultural University \\ Beijing 100094, P.R.. China
}

\begin{abstract}
Two experiments were conducted to examine the difference of nitrogen contents determined by the combustion $(\mathrm{Cm})$ and Kjeldahl $(\mathrm{Km})$ method and its response to nitrate nitrogen in ruminant feedstuffs. In Experiment 1, 14 ruminant feedstuffs were determined for combustion nitrogen $(\mathrm{Cn})$, Kjeldahl nitrogen $(\mathrm{Kn})$ and nitrate nitrogen $\left(\mathrm{NO}_{3}-\mathrm{N}\right)$. Although $\mathrm{NO}_{3}-\mathrm{N}$ resulted in a difference between the $\mathrm{Cm}$ and $\mathrm{Km}$, the correlation coefficient of the $\mathrm{NO}_{3}-\mathrm{N}$ content and the value of "Cn-Kn" was low $\left(\mathrm{R}^{2}=0.6341\right)$, suggesting other factors influencing the difference of $\mathrm{N}$ determination between the $\mathrm{Cm}$ and $\mathrm{Km}$. In Experiment 2, recoveries of net $\mathrm{NO}_{3}-\mathrm{N}$ were determined using Chinese wild rye-grass (CWG), maize grain (MG) and soyabean meal (SBM) supplemented with sodium nitrate at the level of $5,10,15,20,25,30,35,40$ and $45 \%$ on DM basis, respectively. The results showed that different recoveries of $\mathrm{NO}_{3}-\mathrm{N}$ by $\mathrm{Km}$ rather than $\mathrm{Cm}$ would account for the difference of $\mathrm{Cn}$ and $\mathrm{Kn}$ in some ruminant feedstuffs.
\end{abstract}

KEY WORDS: crude protein, nitrate nitrogen, Kjeldahl method, combustion method

\section{INTRODUCTION}

Many researchers have compared $\mathrm{N}$ contents of feedstuffs determined by the combustion (Cm) and Kjeldahl (Km) methods (Koenig, 1991; Jakob et al., 1995). The results revealed a high linear correlation (0.992 0.999) of $\mathrm{N}$ contents for the majority of feedstuffs between the two methods. However, when the feedstuff is rich of $\mathrm{NO}_{3}-\mathrm{N}$, the higher $\mathrm{N}$ content was obtained from $\mathrm{Cm}$ than $\mathrm{Km}$ (Watson and

\footnotetext{
* Supported by National Outstanding Young Scientist Foundation, No. 30125033 and National Natural Science Foundation of China, No. 30270944

${ }^{1}$ Corresponding author: e-mail: qxmeng@cau.edu.cn
} 
Galliher, 2001). Simonne et al. (1997) stated that $\mathrm{Cm}$ and $\mathrm{Km}$ may recover different forms of $\mathrm{N}$ in plant tissues respectively, e.g., nucleic acids $\mathrm{N}$ and $\mathrm{NO}_{3}-\mathrm{N}$. Afterward, Simonne et al. (1998) further demonstrated that under a wide range of $\mathrm{NO}_{3}-\mathrm{N}$ in 130 leaf samples, $\mathrm{NO}_{3}-\mathrm{N}$ alone did not account for the difference between $\mathrm{Cm}$ and $\mathrm{Km}$.

When we routinely determined the $\mathrm{N}$ content of ruminant feedstuffs including forages and vegetables, $\mathrm{Cn}$ contents are always higher than $\mathrm{Kn}$, regardless of their $\mathrm{NO}_{3}$ contents. This observation suggests that there may exist other factors responsible for the difference of $\mathrm{N}$ contents determined between $\mathrm{Cm}$ and $\mathrm{Km}$. Therefore, the present study was conducted to: 1 . prove if the $\mathrm{NO}_{3}-\mathrm{N}$ alone can account for the difference between $\mathrm{Cm}$ and $\mathrm{Km}$ in ruminant feedstuffs, and 2 . explore the factors influencing the difference of $\mathrm{N}$ determination between the two methods, when incremental amounts of $\mathrm{NO}_{3}-\mathrm{N}$ were included in the feedstuffs.

\section{MATERIAL AND METHODS}

Two experiments were conducted in this study. In Experiment 1, 14 feedstuff samples were selected for determination of $\mathrm{N}$ contents: rye-grass, Chinese wild rye-grass (CWG), perfoliate rosin-weed, awnless bromegrass, lucerne, India lettuce, crested wheat-grass, dahuria lyme-grass, sorghum hybrid Sudan-grass, maize stalks, wheat straw, rice straw, grass and cabbage. All samples were dried in a forced-air oven at $70^{\circ} \mathrm{C}$ for $72 \mathrm{~h}$ and ground in a vortex mill $(0.5 \mathrm{~mm}$ sieve, Perten Laboratory Mill 3100). The Kjeldahl-N (Kn), combustion-N (Cn) and nitrogen nitrate $\left(\mathrm{NO}_{3}-\mathrm{N}\right)$ content were then determined for each sample. In Experiment 2, ten incremental levels of sodium nitrate (S5506, Sigma-Altrich) were mixed with Chinese wild rye-grass $(\mathrm{CWG})$, maize grains $(\mathrm{MG})$ or soyabean meal $(\mathrm{SBM})$ to form the sodium nitrate concentration of $5,10,15,20,25,30,35,40$ and $45 \mathrm{~g} / 100 \mathrm{~g}$ dry matter. Nitrogen contents of the samples were determined by the procedure of AOAC (2000) for Kn with the N Analyzer (Foss Model 2300, Sweden) and by the procedure of AOAC (990.03) for Cn with the N Analyzer (Rapid N III, Elementar, Germany). All results were expressed in g N/100 g dry matter (\%). Recovery of $\mathrm{NO}_{3}-\mathrm{N}$ in three serial mixed samples in Experiment 2 was calculated based on the assumption that all ammonia- $\mathrm{N}$ was totally captured into $\mathrm{Kn}$.

In order to determine the $\mathrm{NO}_{3}-\mathrm{N}, 1 \mathrm{~g}$ sample was weighed into a beaker with $50 \mathrm{ml}$ deionized water, then mixed for $1 \mathrm{~h}$ and filtered. $\mathrm{NO}_{3}-\mathrm{N}$ in solution was then measured by the procedure of Jones and Case (1990) using a spectrophotometer (UV-VIS 8500, Shanghai Tianmei Scientific Instrument Co., Ltd., China).

The $\mathrm{N}$ content of feedstuffs was analysed as a single factor design using the GLM procedure of SAS (2003). Simple linear correlation analysis and significance test of the coefficient were performed on $\mathrm{N}$ according to the procedure described by Steel and Torrie (1960). Analysis of correlation between $\mathrm{NO}_{3}-\mathrm{N}$ and $\mathrm{Cn}-\mathrm{Kn}$ was evaluated 
using regression analysis procedure of SAS (2003). The recovery of $\mathrm{NO}_{3}-\mathrm{N}$ in samples was evaluated with an analysis of variance using the GLM procedure of SAS (2003).

\section{RESULTS AND DISCUSSION}

Nitrogen $(\mathrm{N})$ contents of 14 nitrate-contained feedstuffs were determined by both $\mathrm{Cm}$ and $\mathrm{Km}$ (Table 1; Experiment 1). Higher $\mathrm{N}$ content was obtained for $\mathrm{Cm}$ compared with $\mathrm{Km}$ for all feedstuffs $(\mathrm{P}<0.05$; $\mathrm{CV}<5 \%$; $\mathrm{Cn}: \mathrm{Kn}=1.04 \sim 1.21)$. These results were in agreement with the observations of Simonne et al. (1997), who found that sulphuric acid could convert all protein $\mathrm{N}$ and only part of $\mathrm{NO}_{3}-\mathrm{N}$ into ammonium $\mathrm{N}$. In contrast, when the sample contained substantial $\mathrm{NO}_{3}-\mathrm{N}, \mathrm{Cm}$ provided a higher $\mathrm{N}$ measurement (Watson and Galliber, 2001). In the present study, although a linear correlation $(\mathrm{r}=0.9960)$ of $\mathrm{N}$ contents of 14 feedstuffs between the two determination methods as shown in Figure 1, the slope of the regression equation was significantly $(\mathrm{P}<0.01)$ different from that of $\mathrm{Y}=\mathrm{X}$, suggesting other forms of $\mathrm{N}$ (e.g., nitrate $\mathrm{N}$ ) not only ammonium $\mathrm{N}$ included in the feedstuffs. In order to prove the nitrate $\mathrm{N}$ responsible for the difference of $\mathrm{N}$ measurements between the two methods, we made a correlation between nitrate nitrogen $\left(\mathrm{NO}_{3}-\mathrm{N}\right)$ content

Table 1 . Nitrogen contents ( $\% \mathrm{DM})$ of 14 feedstuffs as determined by the combustion and Kjeldahl method (Experiment 1)

\begin{tabular}{lccccccc}
\hline \multirow{2}{*}{ Feedstuffs } & \multicolumn{7}{c}{ Determination method } \\
\cline { 2 - 8 } & $\mathrm{Cn}$ & $\mathrm{CV}^{2}$ & $\mathrm{Kn}$ & $\mathrm{CV}$ & $\mathrm{C} / \mathrm{K}$ & $\mathrm{SEM}$ & $\mathrm{P}$ \\
\hline Maize stalk & $1.05^{\mathrm{a}}$ & 0.34 & $0.93^{\mathrm{b}}$ & 2.06 & 1.13 & 0.010 & 0.012 \\
Chinese wild rye-grass & $1.04^{\mathrm{a}}$ & 0.23 & $0.94^{\mathrm{b}}$ & 1.53 & 1.10 & 0.007 & 0.012 \\
Wheat straw & $0.72^{\mathrm{a}}$ & 1.65 & $0.59^{\mathrm{b}}$ & 1.19 & 1.21 & 0.007 & 0.006 \\
Rice straw & $0.90^{\mathrm{a}}$ & 0.41 & $0.74^{\mathrm{b}}$ & 0.69 & 1.21 & 0.003 & 0.001 \\
Grass & $3.72^{\mathrm{a}}$ & 0.07 & $3.58^{\mathrm{b}}$ & 0.07 & 1.04 & 0.002 & 0.000 \\
Rye-grass & $2.25^{\mathrm{a}}$ & 0.33 & $1.98^{\mathrm{b}}$ & 1.94 & 1.14 & 0.020 & 0.010 \\
Lucerne & $4.58^{\mathrm{a}}$ & 0.42 & $4.03^{\mathrm{b}}$ & 0.59 & 1.05 & 0.004 & 0.000 \\
Perfoliate rosin-weed & $3.32^{\mathrm{a}}$ & 0.14 & $3.16^{\mathrm{b}}$ & 0.10 & 1.14 & 0.012 & 0.010 \\
Awnless brome-grass & $3.34^{\mathrm{a}}$ & 0.36 & $3.12^{\mathrm{b}}$ & 1.31 & 1.07 & 0.021 & 0.017 \\
Crested wheat-grass & $1.11^{\mathrm{a}}$ & 0.57 & $1.03^{\mathrm{b}}$ & 1.72 & 1.07 & 0.009 & 0.030 \\
Dahuria lyme-grass & $1.30^{\mathrm{a}}$ & 0.43 & $1.26^{\mathrm{b}}$ & 0.10 & 1.04 & 0.003 & 0.008 \\
Sorghum hybrid Sudan-grass & $1.74^{\mathrm{a}}$ & 0.12 & $1.61^{\mathrm{b}}$ & 0.94 & 1.08 & 0.008 & 0.008 \\
India lettuce & $3.17^{\mathrm{a}}$ & 0.24 & $2.70^{\mathrm{b}}$ & 0.38 & 1.17 & 0.006 & 0.000 \\
Cabbage & $3.41^{\mathrm{a}}$ & 0.33 & $3.00^{\mathrm{b}}$ & 0.92 & 1.14 & 0.015 & 0.003 \\
\hline
\end{tabular}

${ }_{1 \mathrm{a}, \mathrm{b}}$ means within a line with a different superscript letter differ $(\mathrm{P}<0.05) ;{ }^{2} \mathrm{CV}$ - variance coefficient;

${ }^{3} \mathrm{Cn}$ - combustion nitrogen; Kn - Kjeldahl nitrogen 
and $\mathrm{Cn}-\mathrm{Kn}$ for 14 feedstuffs (Figure 2). No significantly linear correlation was obtained between the $\mathrm{NO}_{3}-\mathrm{N}$ contents and $\mathrm{Cn}-\mathrm{Kn}\left(\mathrm{R}^{2}=0.6341\right.$; Figure 2$)$, suggesting that $\mathrm{NO}_{3}-\mathrm{N}$ alone does not account for the difference between the two methods. This observation coincides with the result of Simonne et al. (1998), who found not only nitrate $\mathrm{N}$ but other factors, such as the nucleic acid, the matrix effect or a combination of both, may explain these differences in vegetable leaves. Further studies are required to prove the validity of this hypothesis.

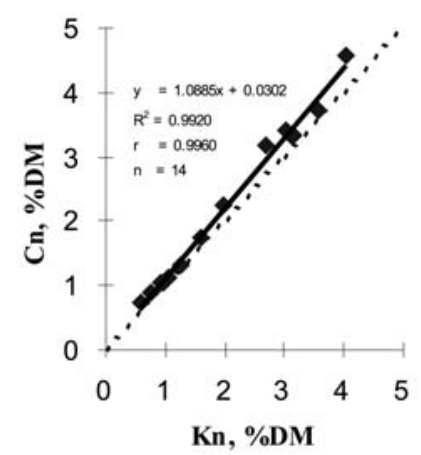

Figure 1. Relation of $\mathrm{N}$ contents of 14 Figure 2. Relation between $\mathrm{NO}_{3}-\mathrm{N}$ contents and $\mathrm{Cn}$ feedstuffs as determined by the $\mathrm{Cm}$ and $\mathrm{Km} \quad-\mathrm{Kn}$ in 14 feedstuffs (Experiment 1) (Experiment 1)

As shown in Tables 2 and 3 (Experiment 2), the recovery of net $\mathrm{NO}_{3}-\mathrm{N}$ of 3 nitrate contained feedstuffs determined by $\mathrm{Cm}$ ranged from 89.2 to $100.5 \%$, whereas the range of $\mathrm{Km}$ was from 34.2 to $54.9 \%$. The $\mathrm{Cm}$ can well capture

Table 2. The recovery of nitrate nitrogen in 3 feedstuffs determined by Kjeldahl method ${ }^{1}$ (Experiment 2)

\begin{tabular}{cccccc}
\hline $\begin{array}{c}\text { Addition level } \\
\text { DM \% }\end{array}$ & \multicolumn{3}{c}{ Kjeldahl method } & \multirow{2}{*}{ SEM } & \multirow{2}{*}{ P } \\
\cline { 2 - 4 } & CWG & CG & SBM & & 0.008 \\
10 & $34.2^{\mathrm{b}}$ & $54.9^{\mathrm{a}}$ & $54.3^{\mathrm{a}}$ & 1.94 & 0.008 \\
15 & $34.6^{\mathrm{b}}$ & $51.9^{\mathrm{a}}$ & $53.2^{\mathrm{a}}$ & 1.74 & 0.001 \\
20 & $34.6^{\mathrm{b}}$ & $51.3^{\mathrm{a}}$ & $52.9^{\mathrm{a}}$ & 0.92 & 0.000 \\
25 & $38.2^{\mathrm{c}}$ & $50.3^{\mathrm{a}}$ & $53.5^{\mathrm{a}}$ & 0.61 & 0.000 \\
30 & $38.0^{\mathrm{c}}$ & $50.3^{\mathrm{b}}$ & $53.7^{\mathrm{a}}$ & 0.65 & 0.014 \\
35 & $37.0^{\mathrm{b}}$ & $48.9^{\mathrm{a}}$ & $50.6^{\mathrm{a}}$ & 1.52 & 0.014 \\
40 & $35.2^{\mathrm{b}}$ & $46.6^{\mathrm{a}}$ & $53.4^{\mathrm{a}}$ & 1.87 & 0.001 \\
45 & $36.1^{\mathrm{b}}$ & $47.2^{\mathrm{a}}$ & $47.4^{\mathrm{a}}$ & 0.52 & 0.000 \\
\hline
\end{tabular}

${ }^{1}$ means within the same line with different superscript letters differ $(\mathrm{P}<0.05)$

${ }^{2}$ no differences were obtained between $\mathrm{NO}_{3}-\mathrm{N}$ addition levels $(\mathrm{P}>0.05)$

${ }^{3} \mathrm{CWG}$ - Chinese rye-grass; $\mathrm{MG}$ - maize grain; SBM - soyabean meal 
Table 3. The recovery of nitrate nitrogen in 3 feedstuffs determined by combustion method ${ }^{1}$ (Experiment 2)

\begin{tabular}{cccrcc}
\hline $\begin{array}{c}\text { Addition level } \\
\text { DM \% }\end{array}$ & \multicolumn{3}{c}{ Combustion method } & \multirow{2}{*}{ SEM } & \multirow{2}{*}{$\mathrm{P}=$} \\
\cline { 2 - 4 } & CWG & MG & SBM & & \\
\hline 5 & $89.2^{\mathrm{b}}$ & $97.8^{\mathrm{a}}$ & $98.5^{\mathrm{a}}$ & 1.78 & 0.034 \\
10 & $89.4^{\mathrm{b}}$ & $98.3^{\mathrm{a}}$ & $98.2^{\mathrm{a}}$ & 1.05 & 0.012 \\
15 & $88.3^{\mathrm{b}}$ & $99.1^{\mathrm{a}}$ & $100.3^{\mathrm{a}}$ & 0.82 & 0.004 \\
20 & $91.8^{\mathrm{b}}$ & $98.4^{\mathrm{a}}$ & $98.8^{\mathrm{a}}$ & 0.32 & 0.001 \\
25 & $91.9^{\mathrm{b}}$ & $98.9^{\mathrm{a}}$ & $100.1^{\mathrm{a}}$ & 0.49 & 0.002 \\
30 & $95.4^{\mathrm{c}}$ & $98.7^{\mathrm{b}}$ & $100.4^{\mathrm{a}}$ & 0.28 & 0.002 \\
35 & $95.0^{\mathrm{c}}$ & $98.9^{\mathrm{b}}$ & $100.5^{\mathrm{a}}$ & 0.29 & 0.002 \\
40 & $92.8^{\mathrm{c}}$ & $97.4^{\mathrm{b}}$ & $100.3^{\mathrm{a}}$ & 0.55 & 0.006 \\
45 & $94.4^{\mathrm{b}}$ & $97.5^{\mathrm{a}}$ & $99.5^{\mathrm{a}}$ & 0.49 & 0.011 \\
\hline
\end{tabular}

${ }^{1}$ means within the same line with different superscript letters differ $(\mathrm{P}<0.05)$

${ }^{2}$ no differences were obtained between $\mathrm{NO}_{3} \mathrm{~N}$ addition level $(\mathrm{P}>0.05)$

${ }^{3} \mathrm{CWG}$ - Chinese rye-grass; $\mathrm{MG}$ - maize grain; SBM - soyabean meal

nitrate $\mathrm{N}$ from the feedstuffs, with an acceptable $\mathrm{N}$ recovery range from 89.2 to $100.5 \%$. However, $\mathrm{Km}$ not only partially captures the nitrate $\mathrm{N}$ reflected by the lower nitrate recoveries, but also the captured amount of nitrate $\mathrm{N}$ was varied with the feedstuff source because of significantly different $(\mathrm{P}<0.05)$ recoveries obtained among the different feedstuffs (Table 2). Simonne et al. (1998) stated that besides nitrate $\mathrm{N}$, nucleic acid $\mathrm{N}$ may also be accountable for the difference between $\mathrm{Cn}$ and $\mathrm{Kn}$ of vegetable leaves. However, when we determine the $\mathrm{N}$ content of yeast products rich of nucleic acids using $\mathrm{Cm}$ and $\mathrm{Km}$, there was no difference obtained. The different recoveries of net $\mathrm{NO}_{3}-\mathrm{N}$ for $\mathrm{Km}$ was likely attributed to certain intrinsic substances (e.g., high concentration of lipids, lipoproteins, etc.) within the biological samples that resulted in their incomplete mineralization for mixtures of sulphuric acid. Based on these observations, different captures of nitrate $\mathrm{N}$ in $\mathrm{Km}$ rather than $\mathrm{Cm}$ would be responsible for the difference of $\mathrm{Cn}$ and $\mathrm{Kn}$ in some ruminant feedstuffs.

\section{CONCLUSIONS}

The combustion method is superior to the Kjeldahl method when the feedstuff contains significant quantities of nitrate nitrogen. Nitrate nitrogen alone does not account for the difference between the two methods. Low and different nitrate captures of feedstuff sources determined by Kjeldahl method rather than combustion method would be accountable for the difference between combustion and Kjeldahl nitrogen in some ruminant feedstuffs. 


\section{REFERENCES}

AOAC, 2000. Association of Official Analytical Chemists, Official Methods of Analysis. 17 $7^{\text {th }}$ Edition. Arlingon, VA

Jakob E., Sievert C., Sommer S.Z., 1995. Automated determination of total nitrogen in milk by the Dumas method. Lebensm.-Unters. Forsch. 200, 239-243

Jones J.B., Case W.W., 1990. Sampling, handing, and analyzing plant tissues samples. In: R.L. Westman (Editor). Soil Testing and Plant Analysis. Soil Science Society of America, Madison, WI, pp. 389-427

Koenig E., 1991. Nitrogen and protein concentration in foodstuffs and animal feeds. Biotech. Forum Eur. 8, 25-29

SAS, 2003. SAS User's Guide: Statistics. SAS Institute Inc. Cary, NC

Simonne A.H., Simonne E.H., Eitenmiller R.R., 1997. Could the Dumas method replace the Kjeldahl digestion for nitrogen and crude protein determination in foods? J. Sci. Food Agr. 73, 39-45

Simonne E.H., Harris C.E., Mills H.A., 1998. Does the nitrate fraction account for differences between Dumas-n and Kjeldahl-n values in vegetable leaves? J. Plant Nutr. 21, 2527-2534

Steel R.G.D., Torrie J.H., 1960. Principles and Procedures of Statistics. MaGraw-Hill Book Company, New York

Waston M.E., Galliher T.L., 2001. Comparison of Dumas and Kjeldahl method with automatic analyzers on agricultural samples under routine rapid analysis conditions. Commun. Soil Sci. Plant Anal. 32, 2007-2019 